The immunological effects of asbestos exposure on various lymphocytes such as the regulatory $\mathrm{T}$ cell (Treg), responder CD4 + T helper cell (Tresp), CD8 + cytotoxic T lymphocytes (CTL) and natural killer (NK) cells were investigated. Results show that asbestos exposure impairs anti-tumour immunity through enhancement of regulatory $\mathrm{T}$ cell function and volume, reduction of CXCR3 chemokine receptor in responder CD4 + T helper cells, and impairment of the killing activities of CD8 +cytotoxic T lymphocytes (CTL) and NK cells. These findings were used to explore biological markers associated with asbestos exposure and asbestos-induced cancers, and suggested the usefulness of serum/plasma IL-10 and TGF- $\beta$, surface CXCR3 expression in Tresp, the secreting potential of IFN- $\gamma$ in Tresp, intracellular perforin level in CTL, and surface expression NKp46 in NK cells. Although other unexplored cytokines in serum/plasma and molecules in these immunological cells, including Th17, should be investigated by experimental procedures in addition to a comprehensive analysis of screening methods, biomarkers based on immunological alterations may be helpful in clinical situations to screen the high-risk population exposed to asbestos and susceptible to asbestos-related cancers such as mesothelioma

\section{CONTACT DERMATITIS AMONG WORKERS OCCUPATIONALLY EXPOSED TO FERRONICKEL ALLOYS}

'S Stoleski* , 'J Karadzinska-Bislimovska, 'J Minov, ${ }^{1} \mathrm{D}$ Mijakoski, ${ }^{2} \mathrm{D}$ Stojanovski, ${ }^{1}$ A Atanasovska. 'Institute for Occupational Health of R. Macedonia, WHO Collaborating Centre and GA2LEN Collaborating Centre, Skopje, R. Macedonia; ${ }^{2}$ Private Health Institution 'Dr Dragan Stojanovski', Kumanovo, R. Macedonia

\subsection{6/oemed-2018-ICOHabstracts. 160}

Introduction Many studies have shown that nickel and its alloys can be potential irritants and sensitizers among workers engaged in ferronickel alloy production, and provoke occupational contact dermatitis.

Objective To assess the prevalence of contact dermatitis focusing on allergic contact dermatitis in workers exposed to nickel while producing ferronickel alloys.

Methods A cross-sectional study included 103 male workers (mean age $=49.1 \pm 10.1$ ) employed as ferronickel smelters (duration of exposure 18.2 \pm 11.9 ) with direct contact to nickel. Their findings were compared with a control group of 37 male office workers (mean age $=46.7 \pm 10.6$ ), employed in the same facility, without direct nickel contact, matched for age, smoking habits and socioeconomic status. Evaluation of examined subjects included Nordic Questionnaire on Occupational Skin Diseases (NOSQ-2002/long), physical examination of the skin changes on hands, wrists and forearms, and patch test with $\mathrm{NiSO}_{4}$ (5\%).

Results and discussion Skin rush during six months was registered in $21(20,4 \%)$ exposed worker, and in $4(10,8 \%)$ controls. The prevalence of skin changes, chronic rhinitis, conjunctivitis, and asthma was higher in exposed workers, but without statistical significance. Hand skin efflorescence due to non-occupational substances were present in $10(9,8 \%)$ of exposed workers, and among $2(5,5 \%)$ of controls. There was no significant difference concerning urticaria between two groups, and non-occupational nickel sensitisation (metal buttons, jewellery, etc.). Positive patch test by $5 \% \mathrm{NiSO}_{4}$ was registered in $20(19.5 \%)$ exposed workers and in $2(5.4 \%)$ controls $(p<0.05)$. Significant difference was found between the two groups concerning improvement of skin lesions after temporary elimination of workplace exposure. Positive elimination test was registered among 5 (4.9\%) exposed workers with hand contact dermatitis.

Conclusion Our data confirmed that workplace nickel exposure can cause occupational allergic contact dermatitis among workers producing ferronickel alloys, and determined the need of preventive activities in order to decrease the pathogenic dermal effect of nickel.

\section{EFFECTS OF IL-15 ADDITION ON THE SUPPRESSED INDUCTION OF CTL UPON EXPOSURE TO ASBESTOS}

N Kumagai-Takei* ${ }^{\star}$ Y Nishimura, H Matsuzaki, S Lee, K Yoshitome, T Otsuki. Department of Hygiene, Kawasaki Medical School, Kurashiki, Japan

\subsection{6/oemed-2018-ICOHabstracts. 161}

Introduction Asbestos exposure can cause malignant mesothelioma and lung cancer. However, in contrast, its effect on anti-tumour immunity remains unclear. Our previous study reported that asbestos exposure suppressed the induction of CTL during mixed lymphocyte reactions (MLR), accompanied by the decrease in proliferation of $\mathrm{CD} 8^{+} \mathrm{T}$ cells. Recently, we reported that IL- 2 showed a tendency to increase $\%$ granzyme $\mathrm{B}^{+}$cells in the CFSE-positive $\mathrm{CD}^{+}$lymphocytes without proliferation upon exposure to asbestos. Therefore, we investigated whether IL-15 addition might improve the suppressed induction of CTL upon exposure to asbestos.

Methods For MLR, human PBMCs were cultured with irradiated allogenic PBMCs upon exposure to chrysotile B asbestos at $5 \mu \mathrm{g} / \mathrm{ml}$ for 7 days. After 2 days of culture, IL-15 was added at $1 \mathrm{ng} / \mathrm{ml}$. After 7 days of MLR, PBMCs were collected and analysed for phenotypic and functional markers of $\mathrm{CD}^{+} \mathrm{T}$ cells with fluorescence-labelled anti-CD3, anti-CD8, anti-CD45RA, anti-CD45RO, and anti-granzyme B Abs using flow cytometry.

Result IL-15 didn't recover the asbestos-caused decreases in $\%$ $\mathrm{CD}_{25}{ }^{+}$and $\% \mathrm{CD}_{45 \mathrm{RO}^{+}}$cells and increase in $\% \mathrm{CD}_{45 \mathrm{RA}^{+}}$ cells, but recovered the decrease in cell numbers of $\mathrm{CD}^{+} \mathrm{CD}^{+}$cells and $\%$ granzyme $\mathrm{B}^{+}$cells, in contrast to IL2.

Discussion These results indicate that IL-15 is more effective on recovery from asbestos-caused suppressed induction of CTL than IL-2, although the interfered expressions of cell surface markers were not recovered even by addition of IL-15. Further study about the characteristics of $\mathrm{CD}^{+} \mathrm{CD}^{+}$granzyme $\mathrm{B}^{+}$cells induced by addition of IL-15 will contribute to clarification for the mechanism of asbestos-caused suppression in CTL induction and to finding out a clue to restore it.

\section{EFFECT OF LONG-TERM EXPOSURE TO ASBESTOS ON FUNCTIONAL PROPERTIES OF HUMAN CD8+T CELL LINE}

N Kumagai-Takei*, Y Nishimura, H Matsuzaki, S Lee, K Yoshitome, T Otsuki. Department of Hygiene, Kawasaki Medical School, Kurashiki, Japan

\subsection{6/oemed-2018-ICOHabstracts.162}

Introduction The tumorigenicity of asbestos, which is thought to cause mesothelioma, has been clarified, whereas its effect on anti-tumour immunity remains unclear. In ICOH Congress 2015, we have reported the enhanced decrease in $\%$ perforin $^{+}$ cells of stimulated $\mathrm{CD}^{+}$cells of the patients with malignant 